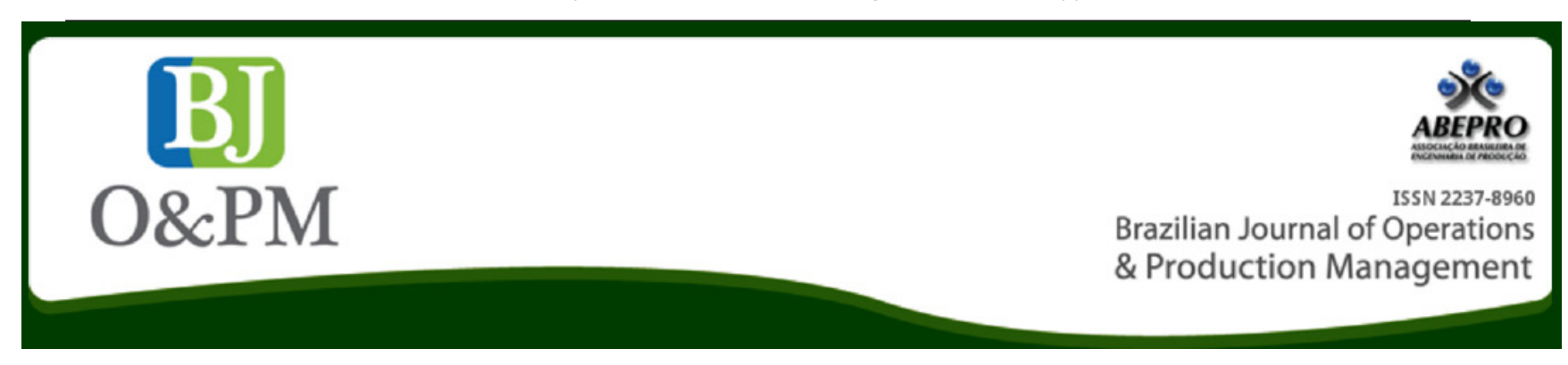

\title{
ASSET AND LIABILITY MANAGEMENT: A MULTIPLE CASE STUDY IN BRAZILIAN FINANCIAL INSTITUTIONS
}

\author{
Priscila da Silva Trasmontano; Julio Vieira Neto ${ }^{a}$ \\ ${ }^{a}$ Fluminense Federal University (UFF) - Niteroi, RJ, Brazil
}

\begin{abstract}
Purpose - In the face of an unstable scenario, many banks began to implement the Asset and Liability Management - ALM, in order to mitigate possible risks, and maximize profitability. In view of this, this study proposes the following problem situation: which managerial resources promote the implementation of ALM and avoid future problems within Brazilian financial institutions? Our objective is to investigate how Brazilian financial institutions are structuring the ALM.
\end{abstract}

Design/methodology/approach - The methodological resource adopted was a Multiple Case Study with qualitative exploratory research based on a perception survey from Brazilian market specialists that deal with ALM in banks and pension funds.

Findings - Among the data collected for implementation, the most prominent were: the identification of assets in which the institution can potentially invest, point estimates of the return on these assets, pertinent legal constraints, parameters used in the development of liquidity constraints and policy constraints adopted by the institution.

Research limitations/implications - This study had the limitation of not dealing with other segments in the case studies, and it did not approach computational models in the context of the national market. However, it is expected that there will be more investment in studies on the theme. Thus, it is suggested that the study is made available in the Brazilian scenario, and the adoption of the model in institutional settings and by other investors.

Practical implications - ALM theme has relevance in its potential to allow the discovery of economic and financial vulnerabilities of an organization, as well as to mitigate their risks.

Originality/ value - The paper may bring more knowledge about this management and the process of implementation in Brazilian financial institutions, particularly in the banking segment, considering that it is still a novel concept in the country.

Keywords: Asset and Liability Management; Brazilian Financial Institutions; Risk; Bank; Pension Fund. 


\section{INTRODUCTION}

A focus on the evolution of Financial Markets allows us to understand that "there has been a significant increase in volume and speed of transactions and a number of leverage sources appeared, maximizing the existing risks as well as the possibilities of losses" (Rieche, 2005, p.221). Equally, given that nations and their respective markets are connected in a network or, in other words, in a "global village", at any given time they are susceptible to being impacted by economic and financial crises, which in turn can disseminate to great proportions, due to the stakeholders' proximity.

Thus, the best chances to survive market volatility lie with those who manage to anticipate it and who have the ability to deal with possible changes - and this applies equally to the Brazilian market. These concepts were the origin of the expression "Asset and Liability Management - ALM", coined in the 1980 's to describe "a model successfully adopted by banks, pension funds, insurance companies, university endowments, hedge and mutual funds, and wealthy individuals" (Mitra et Schwaiger, 2011, p.1).

More specifically, in the year 2008, the world suffered a major economic crisis, resulting from the "bubble burst of subprime credit", related to low quality credit assets, which affected both the United States and Europe, and that reverberated through the other continents. A consequence of that event is that there has been a significant increase in scientific production about ALM and on the demands for risk management, which in turn led to the intensification of the use of that tool (Marques, 2008).

ALM is defined as the "high-level management of a bank's assets and liabilities" (Choudhry, 2011, p.15). In that sense, ALM may be placed both within the scope of Treasury but also within the Asset and Liability Committee - ALCO.

Essentially, this tool manages the interest rate and liquidity risk besides defining the global policy and the credit risk management - albeit at the level of tactics, even if the credit policy is linked to a lower level within the Credit Committees.

In addition, it is "a financial (analytic) tool for decision making that sets out to maximize stakeholder value". It also has as its main objective "to make judicious investments that increase the value of capital, match liabilities and protect from disastrous financial events" (Mitra et Schwaiger, 2011, p.1).

That led to the need for the creation of monitoring mechanisms, and the Basel Capital Accords I, II and III made recommendations for capital management within financial institutions.

The first accord aimed at establishing minimal capital requirements for financial institutions in order to face credit risk, and subsequently, incorporate to the required capital an amount to cover market risks. In Brazil, that was implemented thorough Decision number 2,099 (issued in 1994), which introduced the requirement of minimum capital for financial institutions, in view of the degree of risk of their active operations (Cunha, 2014).

The second sought a more precise measure of the risks incurred by internationally active banks. In Brazil, that happened gradually, starting from Communication number 12,746 (issued in 2004), which dealt with "procedures for the implementation of the new capital structure - Basel II" and which established a simplified schedule for the adjustment, according to the Brazilian Central Bank [BACEN] (2015).

And the third, in addition to considering the liquidity risk of financial institutions, referred to the increase in the quality of regulatory capital, and the need to keep higher quality capital amounts. The adoption of best practices to a bigger number of banks was also recommended (BACEN, 2013; Cunha, 2014).

In Brazil, Communication number 20,615 (issued in 2011), established guidelines in relation to that accord, and presented the schedule for the implementation of recommendations of the Basel Committee on Banking Supervision. BACEN and the National Monetary Council $\mathrm{CMN}$, presented several measures for liquidity management, which contemplated three areas: reserve requirement, operations with the Credit Guarantee Fund - FGC and rediscount (BACEN, 2013; Cunha, 2014).

Talking about ALM implies learning the notion of "Risk". The term usually employed in management, more specifically in "risk management", is "used to describe the length of the confidence interval associated to a given estimate, or to represent the magnitude of the exposure or uncertainty in relation to some expected result" (Rieche, 2005, p.220). In the same way, in the realm of finances, risks may be classified in two categories, as shown in Figure 1: Strategic and Non-Strategic Risks, according to the Brazilian Association of Complementary Pension Fund Entities [ABRAPP] (2011).

In relation to Strategic Risks, those are closely related to decision making by the Chief Executive Officer - CEO, and identified by targets and objectives. However, they present several risks, such as: the market, liquidity, credit and systemic risk (ABRAPP, 2011; Choudhry, 2011; Leão, Martins et Locatelli, 2012a; Rieche, 2005).

Market Risk derives from the volatility of the existing variables in the market, caused by political and other antagonistic factors; from the fluctuation in portfolio value resulting from adverse change in interest rate; from the use derivatives, either for speculation or for hedge; and also for the concentration of collateral assets in certain markets. 


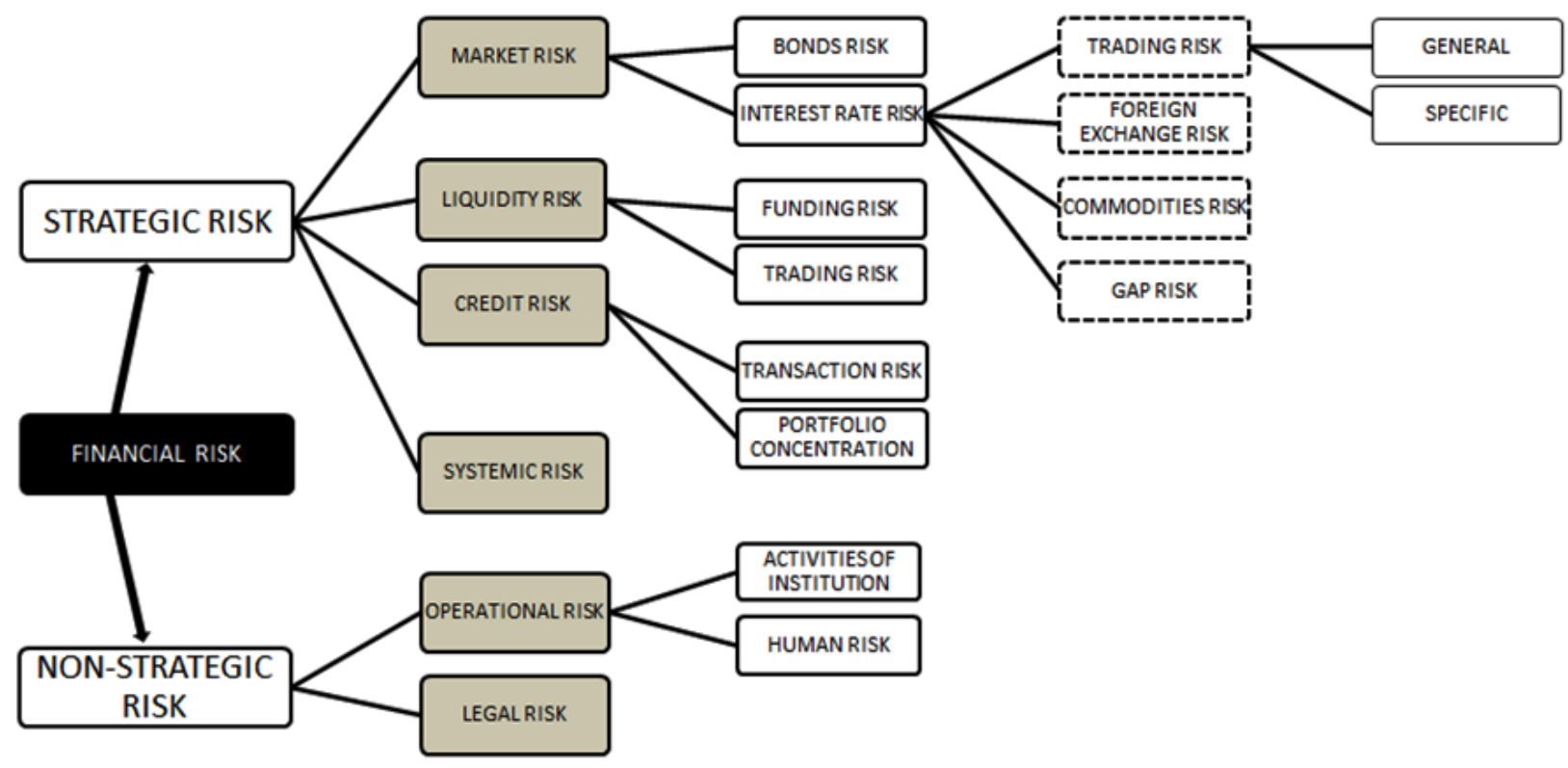

Figure 1. Types of Financial Risks

Sources: Devised by the author, adapted from ABRAPP (2011). Choudhry (2011).Leão, Martins et Locatelli (2012a). Rieche (2005).

As for Liquidity Risk, it is understood as the risk that the bank will not be able to refinance assets as liabilities, for some reason. This results from the timeless differences between cash flow generated by assets and liabilities, which result in lack of resources to meet obligations, leading to the transformation of assets into cash. There is also a financial risk in the possibility of liquidity loss, which can be of two types: market/product and cash flow/obtaining resources.

As for Credit Risk, it derives from the possible occurrence of loss resulting from the non-compliance with an obligation, as well as the lack of capacity to pay by the issuer of a security or the borrower of a loan portfolio; of the excessive concentration in operations with certain counterparts, market segments or geographic regions; of the degradation in the quality of guarantees offered by a borrower, transaction counterpart or issuer of security; and the deterioration in quality of credit attributed to the counterpart, as in cases of rating downgrade of an issuer of security (ABRAPP, 2011).

Finally, Systemic Risk derives from the possibility of the shock affecting a limited part of the segment spreading across the whole system.

On the other hand, Non-strategic Risks are identified from institutional processes, and involve both operational and legal risk (ABRAPP, 2011). Therefore, Operational Risk derives from errors, deficiencies or the inadequacy of internal processes, people and systems, management mistakes, as well as resulting from external events such as natural disasters, fraud, workers' strikes, etc.

With reference to Legal Risk, this refers to the noncompliance with legal or regulatory devices. It may also derives from actions filed by the organization or against them; from formal inadequacies of the contract, the interpretation of its clauses and its conformity with the pertinent legislation; inappropriate interpretation of current legislation; and non-adherence to the bylaws, regulations of the benefits plan, code of ethics and other internal regulations.

Given that there are difficulties in understanding the implementation of the ALM in Brazilian financial institutions, by their financial managers with a view to decision making by senior management. According to this, internalizing the ALM culture is not widespread in the local literature, and given the lack of qualified professionals to deal with this topic, this study proposes the following problem situation: Which management resources promote the implementation of ALM and at the same time avoid future problems within Brazilian financial institutions?

It can be inferred that "Although the topic has been largely discussed in the international business scenario, the literature on the subject in Brazil is scarce" (Leão, Martins et Locatelli, 2012a, p.5). In that sense, this study aims at addressing the topic "Asset and Liability Management ALM" in a comprehensive manner.

The study sets out to investigate the way in which Brazilian financial institutions are structuring the Asset and Liability Management - ALM. By means of studying several cases on the theme, and based on the reality of these organizations, the participants' reports collected highlighted essential elements for the implementation of this tool and potential hindrances. 


\section{METHOD}

The present is an exploratory study, in the case study format, based on a survey of perception. The exploratory survey, shaped by its objectives, enabled a focus on the problem, to make it more explicit, or in other words, that can be understood. The study encompassed elements such as: bibliographic inventory, interviews with people who had practical experiences with the problem under research, and analysis of the examples which "stimulate understanding" (Gil, 2002, p.41).

First, in view of the theoretical and conceptual foundation of the study, a bibliographic inventory was done at the Library of the Technology, Business Management and the Environment Laboratory of the Federal Fluminense University - LATEC/UFF and the author's own archives, as well as electronic research in scientific virtual environments of the Brazilian Digital Library of Theses and Dissertations BDTD, and the Coordination for the Improvement of Higher Education Personnel - CAPES Portal Periodicals, access to the SciVerse Scopus - Scopus database. This was made possible through the use of the keywords, "Gestão de Ativos e Passivos" and "Gerenciamento de Ativos e Passivos", in Portuguese and "Asset and Liability Management", in English.

The second stage of the study unfolded into a case study and multiple cases (Godoy, 1995), whereby focus was put on the object "ALM", by apprehending concepts and scientific investigation, as well as through the perceptions of individuals who belong to different financial institutions, and who for that reason have familiarity with the theme. Thus, one of the outcomes of the use of multiple cases is the formulation of a general explanation that encompasses all cases individually, although they may vary in some particular aspects (Yin, 2001).

As research tools for data collections, two structured questionnaires were devised, with the purpose of "collecting opinions, beliefs, feelings, interests, expectations, situations experienced" (Gerhardt et Silveira, 2009, p.69). In observance of the norms, "the questionnaire must be preceded by a letter of explanation or authorization of the study, referring to its contents, to the instructions for the implementation of the investigation through the questionnaire", accompanied by a "request for authorization and acknowledgement for the attention, availability and truthfulness of the information given" (Kauark, 2010, p.58).

The topics above were formulated in open and closed questions, and in a mixed format. Therefore, there were questions which participants responded freely, as they wished, and closed questions, when participants chose one alternative among those presented in a list, signaling that which best corresponded to what they wished to express. However, in relation to the mixed questions, within a predetermined list there were open items, as for example "others" (Gerhard \& Silveira, 2009).

The two questionnaires applied were not based on a scale, in other words, there was no intention to adopt instruments from third parties, given that those were exclusively developed by the author, through the bibliometric analysis of articles and survey of the more pertinent themes for the study. Thus, the first questionnaire answered by participants contained questions of a socio-ethnographic nature, aiming at describing and revealing, in a broad sense, the social group interviewed (Godoy, 1995). The second questionnaire presented questions relevant to the theme under investigation, i.e., "ALM".

The data collection phase took place after the presentation and approval of the thesis project by the Examination Board of the Federal Fluminense University UFF, on June $13^{\text {th }}, 2015$. More precisely, the data collection with ALM specialists took place between June $22^{\text {nd }} 2015$ and July $24^{\text {th }} 2015$. The two questionnaires were sent to subjects by email, for cognizance of their content prior to the scheduling and conduction of the interview, accompanied by an Introduction Letter of the author as a candidate of the Stricto Sensu Postgraduate Program.

In addition, research participants were asked to submit a mini résumé, as evidence of qualification, with the guarantee that participants and the organizations they work for would not be identified, but just clustered by areas of knowledge and market segment.

Specialists were approached through ALM management, instructors and consultants working in the Brazilian market. Interviews were conducted both face to face and via teleconference, depending on each participant's availability, and the publishing of data for academic and scientific purposes was authorized by participants, subject to confidentiality of identification. The same applied to the audio recordings, which had an average duration of fortytwo minutes.

\section{DESCRIPTION OF THE CASE}

The present study is based on ten ALM specialists who work in the Brazilian market and who are introduced in each case - first, there are six participants from the "banking" segment, followed by four participants from the "pension fund" segment. Given that authorization was granted for the publishing of data for academic and scientific purposes, provided their identity was kept confidential, participants were identified as "Participant 1", abbreviated for "P1" and subsequently, according to the order in which interviews took place. Participants' names, organizations they are employed by or provide services for, their telephone numbers and email addressed were kept confidential. 
Table 1. Identification and Characterization of Research Participants

\begin{tabular}{|c|c|c|c|c|c|c|c|c|c|}
\hline Participant & $\begin{array}{c}\text { Age } \\
\text { (years) }\end{array}$ & Gender & Education & Area of Study & $\begin{array}{l}\text { Organization } \\
\text { Profile }\end{array}$ & Type of Organization & Segment & Job & $\begin{array}{l}\text { Work with } \\
\text { ALM (years) }\end{array}$ \\
\hline P1 & 30 at 39 & Male & Master & Economics & Private & $\begin{array}{l}\text { Open Complementary } \\
\text { Pension Entity }\end{array}$ & $\begin{array}{l}\text { Pension } \\
\text { Fund }\end{array}$ & Manager & 1 \\
\hline P2 & 30 at 39 & Male & Higher Education & Engineering & Private & Commercial Bank & Bank & Manager & 8 \\
\hline P3 & 30 at 39 & Male & Master & $\begin{array}{c}\text { Business } \\
\text { Administration }\end{array}$ & Public & Development Bank & Bank & Administrator & 7 \\
\hline P4 & 50 at 59 & Male & $\begin{array}{c}\text { Lato Sensu } \\
\text { Postgraduate } \\
\text { Course/MBA }\end{array}$ & Economics & Private & Commercial Bank & Bank & Consultant & 7 \\
\hline P5 & 30 at 39 & Male & $\mathrm{PhD}$ & $\begin{array}{l}\text { Actuarial } \\
\text { Science }\end{array}$ & Private & $\begin{array}{c}\text { Financial Consultancy } \\
\text { Agency }\end{array}$ & $\begin{array}{l}\text { Pension } \\
\text { Fund }\end{array}$ & Manager & 12 \\
\hline P6 & 50 at 59 & Male & $\mathrm{PhD}$ & Engineering & $\begin{array}{l}\text { Mixed } \\
\text { Economy } \\
\text { Society }\end{array}$ & Commercial Bank & Bank & Manager & 10 \\
\hline P7 & 40 at 49 & Male & $\begin{array}{c}\text { Lato Sensu } \\
\text { Postgraduate } \\
\text { Course/MBA }\end{array}$ & Engineering & Private & $\begin{array}{c}\text { Financial Consultancy } \\
\text { Agency }\end{array}$ & Bank & Director & 13 \\
\hline P8 & 40 at 49 & Male & Master & Economics & Public & Development Bank & Bank & Manager & 4 \\
\hline p9 & 40 at 49 & Male & Master & Engineering & Private & $\begin{array}{c}\text { Closed } \\
\text { Complementary } \\
\text { Pension Entity }\end{array}$ & $\begin{array}{l}\text { Pension } \\
\text { Fund }\end{array}$ & Manager & 13 \\
\hline P10 & 40 at 49 & Male & $\begin{array}{l}\text { Lato Sensu } \\
\text { Postgraduate } \\
\text { Course/MBA }\end{array}$ & Economics & Private & $\begin{array}{c}\text { Closed } \\
\text { Complementary } \\
\text { Pension Entity }\end{array}$ & $\begin{array}{l}\text { Pension } \\
\text { Fund }\end{array}$ & Manager & 2 \\
\hline
\end{tabular}

Source: Devised by the Author, 2015

3.1. Identification and characterization of research participants

On the basis of data collected as a result from participants' answers to Questionnaire 1, it was possible to identify and characterize the total sample of research participants. Table 1 represents an overview of the total sample under analysis, whose data were detailed later on.

\subsubsection{Age range of research participants}

It can be noted that ALM specialists who took part in this study are above 30 years of age, and the majority are below 49 years of age. Only two participants are between 50 and 59. The $20-29$ and above 60 years of age brackets had no participants.

\subsubsection{Research participants' gender}

It can be seen that all participants were male. Therefore the result is null for female gender.

\subsubsection{Level of schooling of research participants}

Most participants are postgraduates with Masters degrees and emphasis on Finance. Besides, examining these specialists mini résumé, it can be seen that they have international certification in this area. There were also PhDs among those interviewed.

\subsubsection{Research participants' areas of study}

Within the areas of study identified the following were found: Business Administration, Actuarial Science, Economic
Science and Engineering. Within the latter, Electrical, Mechanic and Production Engineering were found. Thus, these professionals are qualified in the Knowledge Areas of Applied Social Sciences and Engineering.

\subsubsection{Profile of the organization of the research participants}

Among the interviewees, the organization more strongly represented was the private sector, with seven participants, while there were only two from the public sector. Another profile identified was that of the mixed capital society, constituted of public and private capital.

\subsubsection{Types of organization of research participants}

In decreasing order of occurrence, the following participation can be identified: three ALM specialists who work for commercial banks, two who work for development banks, two in financial consultancy, two in Complementary Pension Closed Entities - EFPC, and one who works for a Complementary Pension Open Entity - EAPC. There was a null result for participants from financial institutions such as development agencies, investment banks, multiple banks and the Caixa Econômica (Brazilian Savings Bank).

\subsubsection{Market segment of the research participants organizations}

In relation to the market segment, this study counted on the participation of six ALM specialists who work for banks (participants P2, P3, P4, P6, P7 and P8) and four who work for pension funds (participants $\mathrm{P} 1, \mathrm{P} 5, \mathrm{P} 9$ and $\mathrm{P} 10$ ). 


\subsubsection{Research participants' job titles}

Due both to the interview script and to participants' mini résumé, it can be seen that most interviewees are executive managers, including administrator, consultant and director.

\subsubsection{Research participants' time length as ALM specialists}

By classifying these professionals' experience in the ALM area in bands of 1 to 5 years, 6 to 10 years, and over 10 years, the distribution turned out to be even with three, four and three participants, respectively, in each band. The participant with fewer years happened to have solid experience in the financial market. Among the most experienced, the average was $12-13$ years in the ALM area.

\section{CASE ANALYSIS AND DISCUSSION}

With the purpose of exemplifying the concepts proposed by using the data obtained from Questionnaire 2 - ALM, an intracase and intercase analysis took place, grouping cases by the market segments contemplated, i.e., "bank" and "pension fund", and in parallel presenting them under the headings: Understanding ALM; ALM Policy; ALM Relevance; Types of Models and Numeric Approaches Adopted; Essential Elements of the ALM Model; Data Collected for the Implementation of an ALM Model; Restrictions for Implementation; Success in the Asset and Liability Management; Impact Obtained; Adoption of ALM Culture in Financial institutions.

\subsection{Intracase Analysis}

This analysis highlighted the main issues commented by research participants in relation to each theme of a particular segment, the coincidence with the literature and new findings, in consonance with the aims of this study.

\subsubsection{Bank}

This study was represented by participants P2, P4 and P6 who work for commercial banks, P3 and P8 who work for development banks, and P7 who works as a financial consultant for a bank.

\subsubsection{Understanding ALM - Banking Segment}

According to the reports, it may be observed that ALM correlates with financial management in an integrated way, with mitigation of the liquidity and market risks, controlling and monitoring of term gaps and of volume of resources in the assets and liabilities indexing, testifying to Deelstra et Janssen's (1998) report on ALM in banks being geared towards the analysis of duration and/or gap management. In parallel, Mitra et Schwaiger (2011) ratify that a model of integrated asset and liability management seeks to find the best investment strategy considering assets and liabilities simultaneously.

\subsubsection{ALM Policy - Banking Segment}

From the interviews conducted, it was identified that the ALM policy is structured within the scope of the Asset and Liability Committee - ALCO in the commercial banks where Participants P2, P4 and P6 work. It could be verified that within ALCO the Liquidity Policies, Minimum Cash, Product Pricing, Funding, Stress, Capital Allocation and Exposure Limits for Market Risk are appreciated.

ALCO is a committee of the bank's senior administration which may get together monthly, weekly or sporadically (Assis, 2014). It is essential that the committee is composed of the President and Vice-President or Executive Director, Treasurer and Business Line Director. In addition, the Head of the ALM Board, Controllership, Risks and Auditing.

Nevertheless, ALM specialists P3 and P8, who work for development banks, report that it is a Financial Committee which decides on these matters. However, management is segmented into the different departments. There is a project currently being developed to promote more integration of the areas. In a different manner, the consultant and supplier of risk systems and ALM, participant P7, deals with concepts of structured ALM policies in his systems.

\subsubsection{ALM Relevance - Banking Segment}

Participants of this study are in agreement on the relevance of the ALM role in highlighting the assets and liabilities profile, provide for their management and, as a consequence, competitive advantage vis-à-vis the best allocation of resources and adherence to the institutional model. According to Leão (2012b), the management of Asset and Liability and the improvement of risk management and control of short, medium and long term portfolios are essential for the correct operation and perpetuity of a bank. There is an expectation that this theme is contemplated in Basel IV, according to P6's report.

4.1.1.4. Types of Models and Numerical Approaches adopted - Banking Segment

The following models and numerical approaches were identified as implemented by the participants in this study:

- In relation to Cash, Cash Flow Forecasting Model by the interest curve of all payables and receivables, Stress Scenario and Minimum Cash;

- In relation to Financial statements, Balance sheets and Income statements, accounts forecasting, with emphasis on Capital, Reference Asset, Return on Investment - ROI;

- Product pricing;

- Inputs: data on assets and liabilities bank operations;

- Outputs: reports on gap analysis, graphs, simulations and forecast Financial statements; 
- Pre-determined scenarios (deterministic) and adoption of the Monte Carlo method;

- Optimization through a stochastic and parametric approach.

It can be perceived that the modelling is done by the Risk Area, like the ALM system developed internally by a multifunction team, supported by a financial consultancy, in view of the operational specificities of each organization. It is also noticed that the ALM methodologies start by measuring the variable interest rate gap, which is the difference between the volume of asset and liability indexed to floating interest rates, given that the financial instruments subject to these rates are those which bring the biggest uncertainty on the future measured result at amortized cost in a bank (Souza, 2014).

In addition, one considers the terms of these assets and liabilities, although the appropriation of interests may occur at different points in time. With that effect, intervals of thirty, ninety, a hundred and eighty days and so on are defined, depending on the need of each organization, in order to demonstrate the assets and liabilities measuring in a given period of time (Souza, 2014).

\subsubsection{Essential Elements in the ALM Model - Banking} Segment

Question number five of the structured questionnaire sought to detect the items in the ALM Model (Kusy et Ziemba, 1986) adopted by research participants in financial institutions. The answers are compiled in Table 2 below, based on the data collected.
Table 2. Essential Elements in the ALM Model - Banking Segment

\begin{tabular}{|c|c|c|c|c|c|c|c|}
\hline \multirow[t]{2}{*}{ Participant } & \multicolumn{7}{|c|}{$\begin{array}{l}\text { Essential Elements in the ALM Model } \\
\text { Banking Segment: selected alternatives }\end{array}$} \\
\hline & a & b & c & d & e & $f$ & g \\
\hline P2 & $x$ & $x$ & & & & $x$ & \\
\hline P3 & $x$ & $x$ & & & $x$ & $x$ & \\
\hline P4 & $x$ & $x$ & $x$ & $x$ & & $x$ & \\
\hline P6 & $\mathrm{X}$ & $x$ & & & $x$ & $x$ & \\
\hline P7 & $x$ & $x$ & & $x$ & $x$ & $x$ & $x$ \\
\hline P8 & $x$ & $x$ & & & $x$ & $x$ & $x$ \\
\hline Incidence & 6 & 6 & 1 & 2 & 4 & 6 & 2 \\
\hline \multicolumn{8}{|c|}{$\begin{array}{l}\text { Alternatives } \\
\text { (a) Multiperiodicity (forecast events) } \\
\text { (b) Simultaneous considerations of assets and liabilities } \\
\text { (c) Transaction costs } \\
\text { (d) Cash flows uncertainty } \\
\text { (e) Incorporating uncertain interest rates into the decision-making process } \\
\text { (f) Legal and policy constraints } \\
\text { (g) Others }\end{array}$} \\
\hline
\end{tabular}

Source: Devised by the Author, 2015.

It can be observed that all banking segment participants in this research checked the elements contained in alternatives "a", "b" and " $f$ ". However, only participant P4 selected alternative " $c$ ". In relation to alternative " $d$ ", that was checked by financial consultants P4 and P7. Alternative "e" was checked by those who work for commercial and development banks P3, P6, P7 and P8. Thus, other elements were signaled by participants $\mathrm{P} 7$ and $\mathrm{P} 8$, such as cash like and profitability of assets and liabilities.

4.1.1.6. Data Collected for the Implementation of an ALM Model - Banking Segment

This topic, dealt with in question number six of the structured form, investigated the data collected for the implementation of an ALM Model in financial institutions (Kusy et Ziemba, 1986). The alternatives checked by ALM specialists are presented in Table 3.

Table 3. Data collected for the implementation of an ALM Model - Banking Segment

\begin{tabular}{|c|c|c|c|c|c|c|c|c|c|c|c|c|c|}
\hline \multirow[t]{2}{*}{ Participant } & \multicolumn{13}{|c|}{$\begin{array}{l}\text { Data Collected for the Implementation of an ALM Model } \\
\text { Bank Segment: selected alternatives }\end{array}$} \\
\hline & $\mathbf{a}$ & b & c & d & e & $f$ & $\mathrm{~g}$ & h & $\mathbf{i}$ & j & k & I & m \\
\hline $\mathrm{P} 2$ & $x$ & $\mathrm{X}$ & & $\mathrm{X}$ & $x$ & & & $\mathrm{x}$ & $\mathrm{X}$ & & & & \\
\hline P3 & $x$ & $x$ & $\mathrm{x}$ & $x$ & $x$ & & $\mathrm{x}$ & $\mathrm{x}$ & $\mathrm{x}$ & $\mathrm{x}$ & $\mathrm{x}$ & $x$ & \\
\hline P4 & $\mathrm{x}$ & $\mathrm{X}$ & $\mathrm{x}$ & $\mathrm{X}$ & $x$ & $\mathrm{x}$ & $\mathrm{x}$ & $\mathrm{x}$ & $\mathrm{x}$ & $\mathrm{x}$ & & & \\
\hline P6 & $x$ & $\mathrm{X}$ & $\mathrm{x}$ & $\mathrm{X}$ & & & & $\mathrm{x}$ & $\mathrm{X}$ & $\mathrm{x}$ & & & \\
\hline P7 & $x$ & $\mathrm{x}$ & $\mathrm{x}$ & $\mathrm{x}$ & $x$ & $x$ & & $\mathrm{x}$ & $\mathrm{x}$ & $\mathrm{x}$ & & & $\mathrm{x}$ \\
\hline P8 & $\mathrm{x}$ & $\mathrm{X}$ & $\mathrm{x}$ & $\mathrm{X}$ & $x$ & & & $\mathrm{x}$ & $\mathrm{x}$ & $\mathrm{x}$ & & & \\
\hline Incidence & 6 & 6 & 5 & 6 & 5 & 2 & 2 & 6 & 6 & 5 & 1 & 1 & 1 \\
\hline
\end{tabular}

Alternatives

(a) The identification of assets in which the bank can potentially invest

(b) Point estimates of the returns on these assets

(c) Point estimates of capital gains (losses) as a function of the time the bank holds the assets

(d) Identification of the liabilities that the bank can potentially sell

(e) Point estimates of the costs of these liabilities

(f) The rate at which deposits are withdrawn

(g) An estimated weighted cost of funds to determine the discount rate

(h) Pertinent legal constraints

(i) Parameters used in the development of liquidity constraints

(j) Policy constraints used by the bank

(k) Estimates of the marginal distributions of the stochastic resources

(I) Unit penalties incurred for shortage or surplus in the stochastic constraints

(m) Others 
It can be verified that the answers are clustered around the data comprised by alternatives "a", "b", "c", "d", "e", "h", "i" and "j". On the other hand, "f", "g", "k", "I" and " $m$ " have low representativeness.

4.1.1.7. Restrictions for Implementation - Banking Segment

It can be noticed that part of the ALM Model develops within financial institutions and this study is recent in Brazil. One of the biggest restrictions found is related to the collection and preparation of the data bank, as well as the establishment of parameters for feeding the system, given the complexity and volume of operations.

In addition, the following were detected: the need for support from senior management, dissemination of the role of ALM within related areas, training of teams, the issue of management centralization and pricing of assets and liabilities.

4.1.1.8. Success in the Management of Assets and Liabilities - Banking Segment

It may be noticed that support from senior administration is reiterated as an essential factor for the implementation of ALM, which may originate from shareholders' demand. The same applies to data treatment, data consistency and criterion definition. Thus, it is observed the change in strategy in view of the predictability of events and the visualization of results through the use of the tool.

\subsubsection{Impact Obtained - Banking Segment}

The impact noticed by research participants in relation to the implementation of an ALM Model is shown in the efficiency of the financial management through comprehension of the dynamics of the organization; the possibility to steer policies, optimize resources, minimize risks through projected scenarios and managerial reports which guide the decision making process; consistency and increased security for stakeholders.

\subsubsection{Adoption of an ALM Culture - Banking Segment}

It can be noticed that the ALM culture is poorly spread within financial institutions, judging from research participants' responses. Among those which have an ALM area or committee, these concentrate the ALM role, although the need to spread the culture with a view to optimizing resources may be noticed. This requires advanced knowledge in finances, both relative to market instruments and of operations, whose operations have a great impact.

\subsubsection{Complementary Pension Entity}

This segment was represented by participants $\mathrm{P} 1$, who works for a Complementary Pension Open Entity - EAPC; P9 and P10, who work for Complementary Pension Closed
Entities - EFPC, and P5, who works as a financial consultant for Pension Funds.

\subsubsection{Understanding ALM - Pension Fund Segment}

The ALM specialists who took part in this study and who work in EAPC and/or EFPC point out that ALM management is concerned with the objectives of the plan, in particular the compliance with the actuarial liability. This view may be found in Gazzoni, Danielli et Silva (2008) who define ALM as the par excellence instrument in strategic business management, due to the subsidies generated on the basis of modern evaluation techniques of the risks related to benefits plans liabilities, as well as their compatibilization with the investment of their guarantor assets.

\subsubsection{ALM Policy - Pension Fund Segment}

It can be observed from participants' responses, that ALM guides the Investment policy of pension funds, whose strategy is dependent upon the type of obligation and/or a resolution perspective. Besides, the segregation of functions pertaining to the areas of ALM operation, assets purchase and sale, and calculates actuarial liabilities was detected.

Rieche (2005) mentions the compulsory character of the annual establishment of this policy which must contain the criteria for resource allocation among the different segments and the aims for the management of each limit; the criteria for hiring legal entities; the evaluation of the macroeconomic scenario in the short, medium and long term; the analysis format in the sectors where investment is intended to happen, among others established by the Complementary Pension National Council - CNPC.

In a complementary way, Bezerra (2008) shows that because of the peculiarities of the Defined Benefit Pension Plan - DB, the Defined Contribution Plan - DC and Variable Contribution Plan - VCP, the tendencies of their Investment policies are outstanding, so the DB aims to reach an actuarial target, whereas the DC or VCP only have a reference target.

\subsubsection{ALM Relevance - Pension Fund Segment}

It can be seen that ALM is essential for the management of pension funds, both for the allocation of resources (asset) and for the payment of benefits (liability) to the mass of participants vis-à-vis their life time and retirement term, contributing to the process of risk management. Hurtado (2008) emphasized that the integrated treatment of assets and liabilities with a view to minimize the gap risk between them is indispensable for the strategy of financial risk management in organizations with actuarial liabilities.

4.1.2.4. Types of Models and Numerical Approaches Adopted - Pension Fund Segment

Among the models and numerical approaches adopted by these specialists, the following were mentioned: the 
Portfolio and Taxes Duration Gap, Stress Test, Markowitz Model, Random Walk, Stochastic Method and Optimization through genetic algorithms.

Therefore, Cardoso and Santoro (2008) call our attention to the need to build a differentiated investment strategy, in accordance with the characteristics of each retirement plan.

4.1.2.5. Essential Elements of the ALM Model - Pension Fund Segment

Question number five of the structured form aimed at checking the items covered by the ALM Model research participants who work in complementary pension organizations, as can be seen in Table 4.

Table 4. Essential Elements in the ALM Model - Pension Fund Segment

\begin{tabular}{|c|c|c|c|c|c|c|c|}
\hline \multirow[t]{2}{*}{ Participant } & \multicolumn{7}{|c|}{$\begin{array}{l}\text { Essential Elements in the ALM Model } \\
\text { Pension Fund Segment: selected alternatives }\end{array}$} \\
\hline & a & b & c & d & e & f & g \\
\hline P1 & $x$ & $x$ & & & & $x$ & \\
\hline P5 & $x$ & $x$ & & $x$ & $x$ & $x$ & $x$ \\
\hline P9 & $x$ & $x$ & & & $x$ & $x$ & $x$ \\
\hline P10 & $x$ & $x$ & & $x$ & $x$ & $x$ & \\
\hline Incidence & 4 & 4 & 0 & 2 & 3 & 4 & 2 \\
\hline \multicolumn{8}{|c|}{$\begin{array}{l}\text { Alternatives } \\
\text { (a) Multiperiodicity (forecast events) } \\
\text { (b) Simultaneous considerations of assets and liabilities } \\
\text { (c) Transaction costs } \\
\text { (d) Cash flows uncertainty } \\
\text { (e) Incorporating uncertain interest rates into the decision-making process } \\
\text { (f) Legal and policy constraints } \\
\text { (g) Others }\end{array}$} \\
\hline
\end{tabular}

Alternatives " $a$ ", " $b$ " and " $f$ " were chosen by all research participants, while there was null result for " $c$ ". Conversely, alternative "e" was checked by the majority, except for participant P1, who works in EAPC. Alternative "d" divided opinions and was considered by the pension fund consultant - P5 - and by the specialist working in EFPC, P10. Other elements were described as administrative costs and portfolio increase by fixed income, by participants P5 and P9, from EFPC respectively.

\subsubsection{Data Collected for the Implementation of an ALM} Model - Pension Fund Segment

Question number six in the structured form sought to analyze the data collected for the implementation of an ALM Model, as shown in Table 5, and the specialists who took part in this study adapted the items listed so they fit complementary pension fund organizations.

The outstanding alternatives as perceived by these specialists were "a", " $b$ ", “ $h$ ", " $i$ " and "j", and new points covered by " $m$ ", such as capital cost, transaction costs of financial instrument exchange, definition of which assets are marked to market and which are marked on the curve, the need to have a robust tool for data treatment, spreading ALM and risk culture associated to the need for return in the long term, dialogue between the actuarial and investment areas in relation to the ALM model, reinvestment process and decision making.

4.1.2.7. Restrictions for Implementation - Pension Fund Segment

Among the restrictions found for the implementation both in development and production models, these can be noticed: the need for improvement of stochastic scenarios, the incorporation of regulatory capital cost for EAPC in the process, the interaction between the actuarial and investment areas, the specification of the very tool and collection of market data for the pricing of bonds and the interest rate structure, as well as the understanding of the role of ALM.

Table 5. Data Collected for the Implementation of an ALM Model - Pension Fund Segment

\begin{tabular}{|c|c|c|c|c|c|c|c|c|c|c|c|c|c|}
\hline \multirow[t]{2}{*}{ Participant } & \multicolumn{13}{|c|}{$\begin{array}{l}\text { Data Collected for the Implementations of an ALM Model } \\
\text { Pension Fund Segment: selected alternatives }\end{array}$} \\
\hline & $\mathbf{a}$ & b & c & d & e & f & g & h & $\mathbf{i}$ & j & k & I & m \\
\hline P1 & $x$ & $x$ & & & & & & $x$ & $x$ & $\mathrm{x}$ & & & $\mathrm{X}$ \\
\hline P5 & $x$ & $x$ & & $x$ & $x$ & & & $x$ & $x$ & $\mathrm{X}$ & & & $\mathrm{X}$ \\
\hline P9 & $x$ & $x$ & $x$ & & & & & $x$ & $x$ & $x$ & & & $\mathrm{X}$ \\
\hline P10 & $x$ & $x$ & & $x$ & $x$ & & & $\mathrm{x}$ & $x$ & $x$ & $x$ & & \\
\hline Incident & 4 & 4 & 1 & 2 & 2 & 0 & 0 & 4 & 4 & 4 & 1 & 0 & 3 \\
\hline \multicolumn{14}{|c|}{$\begin{array}{l}\text { Alternatives } \\
\text { (a) The identification of assets in which the bank can potentially invest } \\
\text { (b) Point estimates of the returns on these assets } \\
\text { (c) Point estimates of capital gains (losses) as a function of the time the bank holds the assets } \\
\text { (d) Identification of the liabilities that the bank can potentially sell } \\
\text { (e) Point estimates of the costs of these liabilities } \\
\text { (f) The rate at which deposits are withdrawn } \\
\text { (g) An estimated weighted cost of funds to determine the discount rate } \\
\text { (h) Pertinent legal constraints }\end{array}$} \\
\hline
\end{tabular}


4.1.2.8. Success in the Asset and Liability Management Pension Fund Segment

Each specialist emphasized what would be considered success in this kind of management and gave distinct opinions in relation to governance, adequacy of the tool, monitoring of the portfolio, alignment of strategy between the foundation and the hired consultancy firm, the norms posed by the regulatory agency and reiteration of the support from senior management and training of the team.

\subsubsection{Impact Obtained - Pension Fund Segment}

The specialists demonstrated the evolution of ALM within the foundations, in particular the impact on market behavior in recent years, and the resulting need to structure an Investment policy which contemplates macro allocations of the portfolio in view of the obligation.

4.1.2.10. Adoption of an ALM Culture - Pension Fund Segment

In relation to the complementary pension entities, a stronger disposition to spread the ALM culture can be noticed, motivated by the efficacy in the use of the tool, even if some organizations need to count on the help of an external consultancy when they have a limited administrative structure.

\subsection{Intercase Analysis}

In view of the reports from research participants as shown in Section 3.1, the content of each case was confronted and their convergence and singularities were demonstrated.

\subsubsection{Understanding of $A L M$}

Both research participants from the banking segment and those from pension fund agree on the use of ALM as a strategic tool for resource allocation, albeit the first highlights the need for an integrated management approach, while the latter worries about the coverage of actuarial liabilities.

\subsubsection{ALM Policy}

While in financial institutions one can find the structure of an Asset and Liability Committee - ALCO or a Financial Committee which defines methodologies, approves policies, limits and scenarios for analysis, and checks on the alignment of the strategy, in the complementary pension organizations one notices that ALM guides the Investment policy, under the criteria established by the Complementary Pension National Council - CNPC.

\subsubsection{ALM Relevance}

It is noticeable that the role of ALM is instrumental for organizations, irrespective of their nature, be it financial or not, given that ALM allows for better management of assets and liabilities in time, therefore optimizing results.

\subsubsection{Types of Models and Numerical Approaches Adopted}

Banks must consider the requirement of the Brazilian Central Bank - BACEN in order to structure the data of their asset and liability operations within the models, while pension funds consider the composition of their portfolios in accordance with the level of investment and the actuarial liabilities.

For a simulation of scenarios, both start from a deterministic ALM until they obtain the optimization through stochastic in which it is possible to make studies according to each objective, besides doing stress tests.

\subsubsection{Essential Elements of the ALM Model}

Alternatives “(a) multiperiodicity (forecast events)”, "(b) simultaneous considerations of assets and liabilities" and "(f) legal and policy constraints" posed in the fifth question of the structured form were selected unanimously among research participants as essential elements of the ALM Model.

As new features for the banking segment, cash like and profitability of assets and liabilities were identified.

Conversely, the administrative cost and the stretching of the fixed income portfolio for the ALM Model within complementary pension fund organizations was noticed.

\subsubsection{Data Collected for the Implementation of an ALM Model}

With respect to the data collected for the implementation of an ALM Model, the alternatives of the sixth question in the structured form which had more prominence among research participants were "(a) identification of assets in which the institution can potentially invest", "(b) point estimates of the return on these assets", "(h) pertinent legal constraints", "(i) parameters used in the development of liquidity constraints" and "(j) policy constraints adopted by the institution".

Besides the above, specialists who work for banks chose "(c) point estimates of capital gains (losses) as a function of the time the bank holds the assets", "(d) identification of the liabilities that the bank can potentially sell" and "(e) point estimates of the costs of these liabilities".

\subsubsection{Restrictions for Implementation}

It can be seen that the great barrier for the implementation of ALM starts with data treatment and the specification of a tool for both cases. Another deciding factor is the support from senior management, an understanding of what the concept entails, the creation of a team, interpretation of the content generated and the impact of decisions which derive from the latter. 
Brazilian Journal of Operations \& Production Management

Volume 13, Número 2, 2016, pp. 194-206

DOI: 10.14488/BJOPM.2016.v13.n2.a6

\subsubsection{Essential Elements for a Successful Implementation of ALM and Occasional Impasses}

Questions numbers eight, nine and ten of the structured form deal with success in the Asset and Liability Management, the impact obtained and the adoption of an ALM culture, respectively, and seek to present the essential elements for a successful ALM implementation and occasional impasses noticed by participants in the present study. The corresponding reports were transported to the word cloud tool TagCrowd with the aim of showing through Figures 2 and 3 the most recurrent words in their segments.

\subsubsection{Essential Elements for a Successful} Implementation of ALM and Occasional Impasses - Banking Segment

With respect to the success in the Asset and Liability Management, an understanding of the dynamics of the bank, their products and financial instruments are crucial for the start of the ALM project in financial institutions. Later on, this project must be supported by senior management, for purposes of resource allocation, facilitating the dissemination of this culture within the organization and allowing for better communication within the areas, considering the possibility of projecting results from the conciliated data generated by accountancy, change strategy in search for more productivity.

As for the impact obtained, the Banking Segment counts on a multifunction team for the design of the ALM project, particularly from Finance, Management and IT; it becomes a central finance unit of a bank, which liaises with areas such as commercial, business, credit, funding and treasury; it generates more comfort and confidence in decision making through simulated scenarios and forecasting, with impact on timeframes, on better financial management, planning, policy making and minimizing risks.

However, the adoption of an ALM culture within these organizations suffers from the ignorance on the power and purpose of the tool, and therefore lack actions to promote it through presentations, incentives linked to target, and/ or training for members of the board of administration, managers and other staff done by multiplying agents of knowledge, who may be external, the very ALM team or a work group created to this end.

\section{$\mathrm{ALM}_{(20) \text { high (7) }}$ area (15) $_{\text {assets (12) }}$ bank $_{(28) \operatorname{cash}(6)}$ \\ place (5) know (10) accountancy (5) culture (6) data (7) money (9) management (7)}

Organization (11) liquidity (9) change (5) liabilities (6) possibility (8) projection (5)

resources $(10)$ result (7) risk (9) understand (8) rate (8)

Figure 2. Essential Elements for a Successful Implementation of ALM and Occasional Impasses - Banking Segment Source: Developed by the Author with the TagCrowd tool, 2015.
4.2.8.2. Essential Elements for a Successful Implementation of ALM and Occasional Impasses - Pension Fund Segment

From the point of view of research participants who work for complementary pension institutions, the success in asset and liability management is closely related to the governance process, to the existence of a committee which decides on this matter, to the training of professionals and the availability of the tool. Participants talked about the monitoring of the portfolio, about the market and liquidity, the integration of investment and actuarial areas. Equally, they emphasize the support from senior management, although there is an Investment policy based on ALM studies.

The impact obtained with the ALM implementation could be observed in the behavior of the portfolios which become better adapted to the liabilities of foundations for a longer period of time, supported by studies which allowed for better portfolio allocation and crucial decisions with special care in relation to the risks involved in the operations.

In this segment, the adoption of an ALM culture is more welcome, given that the need for a study related to planned objectives and their beneficiaries was evident, and the efficacy of providing more grounds for investment decision making was demonstrated.

$\mathrm{ALM}_{(18)}$ area (5) assets (7) portfolio (11) difficulty (6)

study ${ }_{(10)}$ foundation (9) management (9) governance (5) important (8) investment (9) long (6) need (6) pension (6) plan (6) timeframe $_{(10)}$

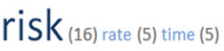

Figure 3. Essential Elements for a Successful Implementation of ALM and Occasional Impasses - Pension Fund Segment.

Source: Developed by the Author with the TagCrowd tool, 2015.

\section{CONCLUSION}

The advances in the global market and its volatility have challenged financial institutions such as banks, and more lately, complementary pension funds types of institutions, insurance brokers, and investors, among other entities, to learn how to manage their resources and to deal with constant risk, therefore, to seek prevention from crisis threats. This led to ALM, a model for the management of assets and liabilities, which is amply spread internationally but started to be discussed in Brazil only recently.

In consonance with the research hypothesis, the management resources which promote the implementation of ALM and which at the same time prevent future problems within financial institutions in Brazil are: support from senior management, understanding of the theme, creation of a team, existence of a committee to discuss and decide on this matter; integration of related areas, improvement of internal controls; mapping of all assets and liabilities within 
the organization (in terms of volume, amount and due date); data treatment; specification of tool; analysis of the differences (gap or mismatch), in other words, gaps; and the creation of policies for action in relation to exposure, for example.

As a result of the study, it is possible to identify the way in which Brazilian financial institutions are getting organized to structure the assets and liabilities management. It must be highlighted that the banking segment is still in development phase; this segment is structured under BACEN requirements and under guidelines of the Basel Accords, in relation to the management of capital and risks (credit, market and liquidity); it involves multifunction groups, with representatives of the finance area (treasury, funding, credit, accountancy and controllership), IT and planning.

In relation to the pension fund segment, ALM is more advanced if compared to the previous segment. The need for this study has been demonstrated, with reference to the objective of the plan and its beneficiary, as well as its efficacy in better informing investment decisions, according to the criteria established by the regulating agency. It was also noticed that ALM facilitated communication between the investment and actuarial areas.

It may be concluded that the reports converge to the literature surveyed, and the ALM theme has relevance in its potential to allow the discovery of economic and financial vulnerabilities of an organization, as well as to mitigate their risks. In addition, it may bring more knowledge about this management and the process of implementation in Brazilian financial institutions, particularly in the banking segment, considering that it is still a novel concept in the country.

This study had the limitation of not dealing with other segments in the case studies, and it did not approach computational models in the context of the national market. However, it is expected that there will be more investment in studies on the theme. Thus, it is suggested that the study is made available in the Brazilian scenario, and the adoption of the model in institutional settings and by other investors.

\section{REFERENCES}

Assis, J. S. (2014). Tendência ALM e Comitê de Ativos e Passivos (ALCO): objetivos do ALCO e ALM. [ALM Trends and the Asset and Liability Committee (ALCO): the objectives of the ALCO and ALM. Text provided by the Integrated Asset and Liability Management Course (ALM)]. São Paulo: FBM Escola de Negócios.

Associação Brasileira das Entidades Fechadas de Previdência Complementar (2011). Gestão baseada em risco. [Brazilian Pension Fund Association (2011). Risk Based Management]. São Paulo: ABRAPP.
Banco Central do Brasil. (2013). Diretoria de Regulação do Sistema Financeiro. Departamento de Normas do Sistema Financeiro. Basiléia III: implantação no Brasil [Slides]. [Brazilian Central Bank (2013). Financial System Regulation Sector. Financial System Norms Department. Basel III: implementation in Brazil [Slides]]. Accessed on February $21^{\text {st }}, 2015$ at http://www.bcb.gov.br/pec/appron/apres/ Apresentacao_Sergio_Odilon_Coletiva_Basileia_III-1-32012.pdf.

Banco Central do Brasil. (2015). Recomendações de Basiléia. [Brazilian Central Bank. (2015) Basel Accords]. Accessed on February 21 2015 at http://www.bcb.gov. br/?BASILEIA.

Bezerra, J. T. F. (2008). Política de Investimentos: tendências para os planos BD, CD e CV. In W. Góes (Coord.). Fundos de pensão: gestão de investimentos. [Investment Policy: trends for DB, DC and VCP plans. In: W. Góes (Coord.). Pension funds: investment management]. São Paulo: ABRAPP/ICSS/ SINDAPP.

Cardoso, A., \& Santoro, R. (2008). Metodologia para formulação da Política de Investimentos. In W. Góes (Coord.). Fundos de pensão: gestão de investimentos. [Methodology for the formulation of Investment Policy. In: W. Góes (Coord.). Pension funds: investment management]. São Paulo: ABRAPP/ ICSS/ SINDAPP.

Choudhry, M. (2011). Bank Asset-Liability and liquidity risk management. In G. Mitra, \& K. Schwaiger (Eds.). Asset and Liability Management Handbook. (Chap. 2, p.15). London: Palgrave Macmillan.

Comunicado n. 12.746, de 09 de dezembro de 2004 (2004). [Communication number 12,746 of December $9^{\text {th }}, 2004$ (2004)]. Describes the procedures for the implementation of the new capital structure - Basel II. Brasília. 2004. Accessed on February 21 $1^{\text {st }}, 2015$ at https://www3.bcb.gov.br/ normativo/detalharNormativo.do? $\mathrm{N}=104206982$ \& method= detalharNormativo.

Comunicado n. 20.615, de 17 de fevereiro de 2011 (2011). [Communication number 20,615 of February 17 th, 2011 (2011)]. Presents preliminary guidelines and schedule relative to the implementation in Brazil, of the recommendations from the Basel Committee on Banking Supervision for capital structure and liquidity requirements (Basel III). Brasília. 2011. Accessed on February 21 ${ }^{\text {st }}, 2015$ at https//www3.bcb.gov.br/normativo/detalharNormativo. do?method=detalharNormativo\&N=111011733.

Cunha, M. M. B. (2014). Os Acordos de Basiléia I, II, III e o mercado bancário brasileiro: um estudo sobre os principais desafios da gestão de liquidez nesse novo cenário. [Basel Accords I, II, III and the Brazilian banking market: a study about the main challenges of liquidity management in this new scenario]. Master's Thesis, Pontifical Catholic University of São Paulo, São Paulo, SP, Brasil. 
Brazilian Journal of Operations \& Production Management Volume 13, Número 2, 2016, pp. 194-206

DOI: 10.14488/BJOPM.2016.v13.n2.a6
Deelstra, G., \& Janssen, J. (1998). Interaction between Asset Liability Management and risk theory: an unsegmented and a multidimensional study. Applied Stochastic Models and Data Analysis, 14 (4), 295-307.

Gazzoni, A. F., Danieli, C. L., \& Silva, D. P. (2008). ALM Asset Liability Management. In W. Góes (Coord.). Fundos de pensão: gestão de investimentos. [Pension funds: investment management]. São Paulo: ABRAPP/ICSS/ SINDAPP.

Gerhardt, T. E., \& Silveira, D. T. (2009). Métodos de Pesquisa. Universidade Aberta do Brasil - UAB/UFRGS \& Curso de Graduação Tecnológica - Planejamento e Gestão para o Desenvolvimento Rural da SEAD/UFRGS (Coord.). [Research Methods. Open University of Brazil - UAB/ UFRGS \& Undergraduate Technical Course - Planning and Management for Rural Development of SEAD/UFRGS (Coord.)]. Porto Alegre: Editora da UFRGS.

Gil, A. C. (2002). Como Elaborar Projetos de Pesquisa. (4a ed.). [How to Plan Research Projects. (4 ${ }^{\text {th }}$ ed.)]. São Paulo: Atlas.

Godoy, A. S. (1995) Pesquisa Qualitativa: tipos fundamentais. Revista de Administração de Empresas, 35 (3), 20-29.[Qualitative Research: fundamental types. Business Management journal 35 (3), 20-29].

Hurtado, N. H. (2008). Análise de metodologias de Gestão de Ativos e Passivos em Planos de Benefício Definido de fundos de pensão: uma abordagem financeiro-atuarial. [Analysis of Assent and Liability Management Methodologies in Defined Benefit Pension Fund Plans: a financial-actuarial approach]. PhD Dissertation, Graduate School of Business of the Federal University of Rio de Janeiro (COPPEAD), Rio de Janeiro, RJ, Brasil.

Kauark, F. S., Manhães, F. C., \& Medeiros, C. H. (2010). Metodologia da pesquisa: um guia prático. [Research Methodology: a practical guide]. Itabuna: Via Litterarum.

Kusy, M.I., \& Ziemba, W.T. (1986). A Bank Asset and Liability Management Model. Operations Research, 34 (3), 356-376.

Leão, L. L., Martins, P. S., \& Locatelli, R. L. (2012a). Gestão de Ativos e Passivos e controle de riscos: um estudo aplicado ao Banco de Desenvolvimento de Minas Gerais S/A. Revista Gestão e Tecnologia, 12 (3), 3-25. [Asset and Liability Management and risk control: a study applied to the Development Bank of Minas Gerais S/A. Management and Technology Journal, 12 (3), 3-25].

Leão, L. L. (2012b). Gerenciamento de Ativos e Passivos, controle de riscos e geração de valor: um estudo aplicado ao Banco de Desenvolvimento de Minas Gerais. [Asset and Liability Management, risk control and value creation: a study applied to the Development Bank of Minas Gerais]. Master's Thesis, Faculdades Integradas de Pedro Leopoldo, Pedro Leopoldo, MG, Brasil.
Marques Filho, D. F. (2008). Gestão de Ativos e Passivos nas instituições financeiras do mercado brasileiro: uma abordagem na alocação de capital. [Asset and Liability Management in financial institutions of the Brazilian market: an approach to capital allocation]. Master's Thesis, Pontifical Catholic University of São Paulo, São Paulo, SP, Brasil.

Mitra, G., \& Schwaiger, K. (2011). Introduction. In G. Mitra, \& K. Schwaiger (Eds.). Asset and Liability Management Handbook. (Chap. 1, p. 1). London: Palgrave Macmillan.

Resolução n. 2.099, de 17 de agosto de 1994 (1994). [Decision number 2,099 of August 17th 1994 (1994)]. Sets forth regulations on conditions for access to the National Financial System, minimum capital amounts and adjusted shareholder's equity, setting up of facilities and the obligation to maintain adjusted shareholder's equity in amounts compatible with the level of risk of asset operations in financial institutions and other institutions authorized to operate by the Brazilian Central Bank. Brasília. 1994. Accessed on February 21 1 st 2015 at http://www.bcb. gov.br/pre/normativos/res/1994/pdf/res_2099_v25_P.pdf.

Rieche, F. C. (2005). Gestão de riscos em fundos de pensão no Brasil: situação atual de legislação e perspectivas. Revista do BNDES, 12 (23), 219-242. [Risk management in pension funds in Brazil: current legal situation and perspectives. BNDES Journal, 12 (23), 219-242].

Souza, E. B. M. (2014). Mensuração e evidenciação do risco financeiro de derivativos. [Measurement and evidencing of the financial risk of derivatives]. PhD Dissertation, Programa de Pós-Graduação em Controladoria e Contabilidade, Departamento de Contabilidade e Atuária, Faculdade de Economia, Administração e Contabilidade, Universidade de São Paulo, São Paulo, SP, Brasil.

Yin, R. K. (2001). Estudo de caso: planejamento e métodos. (2 $\mathrm{a}$ ed.). [Case study: planning and methods. ( $2^{\text {nd }}$ ed.)]. (D. Grassi, Trad.) Porto Alegre: Bookman. (Original work published in 1994). 